\title{
Blaski i cienie neuroestetyki: kilka uwag o naturalizacji badań nad przeżyciami estetycznymi
}

\begin{abstract}
One of the greatest challenges of cognitive science is the application of its methods to explain the phenomena of normative character. One of the attempts on naturalizing philosophy is neuroaesthetics, which utilizes the development of neurosciences to study the neural basis of aesthetical experiences. This area brings much hope in the context of scientific explanation of art and beauty, albeit faces many methodological problems. The main objection is the inadequacy of methods used to the subject of explanation. Despite some of the objections seem correct, this research programme may fruitfully contribute to the aesthetical thought and provide a scientific background of the mental states of that character.
\end{abstract}

Keywords: neuroaesthetics, aesthetics, naturalization of philosophy, neuroscience

„Byłoby rzeczą ciekawą i pouczającą dla poznania naukowego sztuki, jak również dla ogólnej psychologii emocji, zbadać odpowiednie zjawiska emocjonalne, a w szczególności środki i sposoby, których używa sztuka, aby budzić i wzmagać emocje” [Petrażycki 1959].

\section{Wprowadzenie}

Dynamiczny rozwój nowych technologii i metod badawczych w ostatnim stuleciu był jednym z kamieni milowych w powstaniu i rozwoju nauk kognitywnych. Te fundamentalne dla neurobiologii metody, takie jak obrazowanie funkcjonalnym rezonansem magnetycznym czy elektroencefalografia, umożliwiły lepsze poznanie funkcjonowania ludzkiego mózgu. Badania z zakresu neuronauki nie ograniczają się już do czysto biologicznego wyjaśniania funkcjonowania układu nerwowego i jego zaburzeń, ale w wyniku podejścia interdyscyplinarnego próbują dać odpowiedzi także na pytania, które dotąd były przedmiotem głównie refleksji filozoficznej. W ramach niektórych gałęzi nauki budzi to zarówno wielkie nadzieje, jak i kontrowersje. Są one związane choćby z celowością i znaczeniem odkrywania neuronalnych korelatów różnych przeżyć, co dotyczy zwłaszcza tych dziedzin, które są związane z badaniem 
ludzkich sądów o charakterze subiektywnym czy normatywnym. Przykładem takich dociekań może być poszukiwanie biologicznych podstaw moralności [Berker, 2009]. Taki nurt badań można określić jako znaturalizowany. Termin ten upowszechnił Willard Van Orman Quine w kontekście epistemologii i oznacza on wykorzystanie metod nauk przyrodniczych do badania tradycyjnych problemów, które dotąd nie były analizowane z punktu widzenia nauk empirycznych [Rysiew, 2016]. Z jednej strony takie badania dostarczają bardzo wielu interesujących danych na temat ludzkiej natury, z drugiej jednak często łączą się z licznymi problemami i ograniczeniami teoretycznymi o charakterze zarówno czysto metodologicznym, jak i pojęciowo-filozoficznym.

Jedną $\mathrm{z}$ takich bardzo obiecujących, jak i równie kontrowersyjnych dziedzin jest neuroestetyka, czyli neurobiologiczne poszukiwanie źródeł przeżyć estetycznych. Czy znaturalizowanie piękna i sztuki jest w ogóle możliwe? Niniejszy artykuł ma za zadanie naświetlić podstawowe problemy i ograniczenia, $\mathrm{z}$ którymi boryka się neuroestetyka, oraz wskazać jej szanse - w postaci choćby potencjalnych nowych kierunków badań.

\section{Wyzwania neuroestetyki}

Pomysł uprawiania estetyki jako nauki empirycznej i eksperymentalnej nie jest nowy. Wywodzi się od Gustava Fechnera, jednego z twórców psychologii eksperymentalnej. Prowadząc swoje badania, doszedł on do wniosku, że charakterystyka niektórych obiektów, które wydają się przyjemne dla percepcji, może być opisana za pomocą kilku ogólnych zasad: progu estetycznego, jedności w wielości, braku przeciwieństw, stopniowania estetycznego, jedności i jasności oraz kojarzenia [Bremer, 2016]. Warto zauważyć, że takie podejście do badań estetycznych, stosujące metody właściwe dla psychologii poznawczej, wydaje się zbliżone do rozumienia estetyki jako rodzaju poznania zmysłowego. Taka właśnie idea została zaproponowana przez Alexandra Baumgartena i sprzeciwia się Kantowskiemu rozdziałowi namysłu nad pięknem od nauk o poznaniu [Gregor, 1983]. Tym tropem, tj. formułowania ogólnych reguł, którym podporządkowany powinien być obiekt wywołujący przeżycia estetyczne, podążają badacze uznawani za założycieli paradygmatu neuroestetycznego: Semir Zeki i Vilayanur Ramachandran. Drugi spośród tych badaczy przedstawia swoją teorię w artykule Nauka wobec zagadnienia sztuki. Neurologiczna teoria doświadczenia estetycznego, napisanym wspólnie z Williamem Hirsteinem [2006]. Zgodnie z tą teorią fundamentalne znaczenie estetyczne mają następujące zasady: przesunięcia szczytowego, grupowania i łączenia percepcyjnego, izolowania pojedynczego modułu i alokacji uwagi, wydobywania kontrastu, symetrii, zgeneralizowanego punktu widzenia oraz metafory. Później zasady te zostały uzupełnione o dwie kolejne: powtarzania, rytmu i porządku (repetition, rythm and orderliness) oraz równowagi (balance) [Bremer, 2016]. Według Zekiego podstawowe prawa spostrzegania istotne w kontekście postrzegania sztuki są dwa: stałość (constancy), czyli umiejętność postrzegania pewnych własności niezależnie od zmian „środowiskowych”, takich jak oświetlenie czy kąt patrzenia, oraz abstrakcja (abstraction), która określa umiejętność mózgu do tworzenia form ogólnych czy wzorcowych [Zeki, 2012; Bremer, 2016]. Jego zdaniem sztu- 
ka i piękno zakorzenione są w pojęciach mózgowych, które rozumiane są w sposób naturalistyczny, tzn. realizują je określone układy neuronalne. Mogą one być zarówno dziedziczne, jak i nabyte [Zeki, 2012]. Można je porównać do Platońskich idei, a podstawowym zadaniem artystów jest ukazanie tych pojęć w sztuce, mimo że często jest to z pozycji twórcy dzieła nieosiągalne. Ta nieosiągalność może skutkować porzuceniem niedokończonych dzieł, ale również implikować wieloznaczność, czy zostawiać pole wyobraźni dla odbiorców sztuki. Zadaniem odbiorcy jest dopełnienie dzieła za pomocą własnej inwencji, w zgodzie z własnym pojęciem mózgowym. W myśl koncepcji Zekiego artyści są „nieświadomymi neurobiologami”, którzy wykrywają prawa rządzące percepcją w mózgu i oddziałują na niego za pomocą swych dzieł [Bremer, 2016]. Podkreśla on także bardzo istotną rolę wieloznaczności w sztuce, która może zachodzić na poziomie niższym, percepcyjnym, ale i wyższym, gdzie dotyczy treści dzieła i różnych jego interpretacji [Zeki, 2012].

Aby zdefiniować przedmiot badań, należy wprowadzić jakiś sposób rozróżnienia obiektów, które wywołują przeżycia estetyczne (takich jak dzieła sztuki), od tych, które ich nie wywołują. Jedną z takich propozycji przedstawia Giulia Bonasio, analizując teorię estetyczną Franka Sibleya [Bonasio, 2014]. Teoria ta jest dogodnym punktem wyjściowym do analizy badań neuroestetycznych, gdyż za podstawę przeżyć uznaje istnienie pojęć estetycznych, których to poszukiwanie wydaje się celem badaczy $\mathrm{z}$ tego nurtu (w szczególności Zekiego). Za podstawę istnienia estetyki w jakiś sposób zobiektywizowanej przyjmuje konsensus w zakresie przeżyć estetycznych pewnej grupy ludzi. Może być ona jednak niewielka, rozróżnić należy też rodzaje tych grup: czym innym może być bowiem zgoda „potoczna”, a czym innym zgoda krytyków sztuki. Takie założenie wydaje się warunkiem wstępnym badań neuroestetycznych, które mają charakter przede wszystkim ilościowy i posługują się między innymi metodą intersubiektywnej korelacji, czyli badania współwystępowania określonych wzorców aktywacji mózgu. Celem tej metody jest wyekstrahowanie obszarów odpowiedzialnych za przeżycia estetyczne, którymi mogą być na przykład neuronalne korelaty piękna [Kawabata i Zeki, 2004]. Konieczność rozróżnienia między grupami odbiorców widać przykładowo w badaniach nad pięknem matematycznym [Zeki i in., 2014].

Czym mogą być pojęcia estetyczne i jak odróżnić je od pojęć nieestetycznych? W teorii Sibleya pojęcia estetyczne definiowane są poprzez użycie silnie ewaluatywnych określeń, które określane są mianem „tłustych” (thick terms), takich jak piękny, poruszający itp. [Bonasio, 2014]. Thick terms można zdefiniować jako „wyrażenia języka naturalnego, które łączą w sobie element deskryptywny i ewaluatywny" [Skoczeń, 2016, s. 55]. W tym miejscu warto, za G. Bonasio [2014], zwrócić uwagę na fakt, że same pojęcia estetyczne nie muszą mieć charakteru bezpośrednio językowego. Dziecko klaszczące i tańczące do muzyki z pewnością zna takie pojęcia i daje im wyraz w postaci „behawioralnego" sądu estetycznego. Koncepcja ta zakłada, że „tłustość" pojęć, czyli ich dwojaki charakter, przejawiać się będzie w nadbudowaniu elementu ocennego na opisowym. Aspekt estetyczny będzie zatem emergentny wobec jakości, które nie mają bezpośrednio charakteru estetycznego, takich jak kolory [Bonasio, 2014]. Wydaje się, że odpowiedź na pytanie, w jaki sposób kształtuje się ta zależność, jest kluczowym problemem estetyki. W kontekście metafizycznego wyjaśnienia tej relacji proponuje się na przykład superweniencję [Levinson, 1984]. 
Czy rozwiązanie zagadki powstawania tej relacji może przynieść nie czysta filozofia, a zorientowana empirycznie neuronauka? Podejście sceptyczne mogłoby wskazywać, że zakres badawczy neuronauki ogranicza się jedynie do prostej percepcji pojęć nieestetycznych, takich jak formy czy kolory, i w efekcie może co najwyżej ustalać pewne korelacje pomiędzy tymi typami pojęć. Wydaje się jednak, że program badawczy Zekiego poszukuje właśnie sedna estetycznie „tłustych” pojęć. Zarzut ten mógłby być natomiast trafny w odniesieniu do Ramachandrana, którego zestaw reguł wyłapuje pewne charakterystyczne formy, łatwiejsze do percypowania, choć i on akcentuje poszukiwanie pewnych ideałów, które określa terminem „rasa” [Ramachandran i Hirstein, 2006]. Znaczenie tego terminu w kontekście jego teorii szerzej omawia Józef Bremer [2016]. Zaproponowanego przez Zekiego podziału na pojęcia wrodzone i syntetyczne nie można $\mathrm{z}$ kolei utożsamiać $\mathrm{z}$ podziałem na pojęcia nieestetyczne i estetyczne, chociaż w większości te nieestetyczne - takie jak kolor, będą wrodzone, a artysta będzie dążył do zmierzenia się z pojęciami syntetycznymi. Wyjątek dotyczyć będzie sztuki nowoczesnej, abstrakcyjnej, w której to pojęcia wrodzone stają się głównym jej obiektem.

Wydaje się zatem, że program badawczy neuroestetyki może mieć istotny wkład w wyjaśnienie fenomenu przeżycia estetycznego. Jednak krytycy zauważają, że posiada on liczne wady, a nawet kwestionują jego istotę i zasadność. W eseju zatytułowanym Neuroaesthetics Is Killing Your Soul Philip Ball [2013] stwierdza, że poszukiwanie uogólnień w sztuce i odpowiedzi neurofizjologicznych na nie może być interesujące, ale nie pozwoli nam w pełni wyjaśnić czy zdefiniować sztuki, a tym bardziej sztuki bardziej czy mniej wartościowej - podaje przykład noblisty Wilhelma Ostwalda, twórcy wpływowej teorii koloru, który zadeklarował, że Tycjan używał „błędnego” niebieskiego. Zauważa też, że typowe odkrycia neuroestetyczne ograniczają się do stwierdzenia, iż podczas oglądania dzieł sztuki aktywują się obszary odpowiedzialne za odczuwanie przyjemności czy tzw. układ nagrody. Mimo że jest to wartościowa informacja, to „nieodróżnianie Bacha od barbituranów” tworzy poważne ograniczenia [Ball, 2013]. W podobnie prześmiewczym tonie John Hyman [2010] zwraca uwagę na konkretne wady teorii Ramachandrana i Zekiego. W odniesieniu do Ramachandrana skupia się on na krytyce priorytetowej w jego koncepcji zasady przesunięcia szczytowego. Jego zdaniem zasada przesunięcia szczytowego nie może być utożsamiana $\mathrm{z}$ „superbodźcem". Dotyczy ona bowiem jedynie niewielkich przesunięć w reakcji w stronę bardziej wyrazistego bodźca w przypadku, gdy pojawia się bodziec odbiegający od normy. Przesunięcia szczytowego nie można zatem odnieść do przywoływanych przez Ramachandrana rzeźb kobiet, gdyż ich proporcje za bardzo odbiegają od normy. Po drugie, teoria ta nie rozróżnia dzieła sztuki od obiektu przez nie przedstawianego. W tym miejscu Hyman nazywa ją wprost „Baywatch Theory of Art”, zaznaczając, że równie dobrze mogłaby dotyczyć Pameli Anderson, która poprzez powiększenie piersi stworzyła „superbodziec” w kategorii różnic pomiędzy płciami. Po trzecie, kwestionuje przyjmowaną przez Ramachandrana definicję sztuki, która zakłada, że sztuka ma za zadanie wyolbrzymiać, przekształcać lub zniekształcać rzeczywistość. Podaje też liczne kontrprzykłady w zakresie erotycznego przedstawienia kobiet jako dzieł sztuki, które nie podporządkowują się zasadzie „superbodźca”. Stwierdza w podsumowaniu, że największą bolączką teorii Ramachandrana jest zdefiniowanie sztu- 
ki jako zmodyfikowanego przedstawienia rzeczywistości. Szerzej o roli deformacji w neuroestetyce pisze Piotr Przybysz [2006]. Także teoria Zekiego poddana jest przez Hymana silnej krytyce. Po pierwsze, podkreśla on, iż nie jest niczym dziwnym, że kora wzrokowa V5 aktywuje się w przypadku sztuki kinetycznej, V1 - w przypadku składających się z poziomych i pionowych linii dzieł Mondriana itd. To odkrycie nie wyjaśnia, dlaczego dzieła te uznajemy za interesujące czy piękne, co więcej, nie mówi nic specyficznego na temat sztuki w ogóle [Hyman, 2010]. Podobne zarzuty formułuje wobec Zekiego Bremer [2016], akcentując fakt, że zasadniczo jego badania i spostrzeżenia mogą odnosić się prawie wyłącznie do sztuki abstrakcyjnej. Kolejnym punktem krytyki przedstawionej przez Hymana [2010] stało się porównanie artystów do neurologów, którzy poprzez swoje działanie chcą wywrzeć efekt psychologiczny na odbiorcach - to samo mogą robić przecież specjaliści od marketingu, a lody czy hamburgery również wywołują u odbiorców stany psychologiczne i emocjonalne realizowane w specyficzny sposób w mózgu. Również wieloznaczności nie można uznać w prosty sposób za wyróżnik estetyczny, a co więcej, rozważania o niej na wysokim poziomie nie mają zdaniem Hymana w żadnym stopniu charakteru neuronaukowego. W podsumowaniu zauważa on jednak, że dzięki tej nauce można wyjaśnić pewne fenomeny artystyczne - przykładowo, w tworzeniu efektów kolorystycznych przez przedstawicieli impresjonizmu istotną rolę gra pomijanie stronne. Ale teorie przedstawiane przez Ramachandrana i Zekiego są według niego nietrafnymi generalizacjami. Zwraca ponadto uwagę na wybiórczość ich przykładów. Z kolei wysunięty przez Mengfei Huang [2009] zarzut, że wspomniani twórcy neuroestetyki skupiają się tylko na sztuce zachodniej, należy uznać za nieadekwatny, gdyż prezentowane przez nich przykłady pochodzą także choćby ze sztuki indyjskiej [Bremer, 2016].

Oprócz konkretnej krytyki prac Zekiego i Ramachandrana, w literaturze formułuje się też ogólne zastrzeżenia pod adresem całego paradygmatu neuroestetycznego. Bevil Conway i Alexander Rehding zauważają, że neuroestetyka zdefiniowana jako „naukowe badanie neuronalnych stanów obecnych w podmiocie przeżywającym i tworzącym dzieła sztuki" (definicja ta została sformułowana przez Zekiego [Bremer, 2016]) nie może ograniczać się do poszukiwania pojedynczych neuronalnych korelatów piękna (ponieważ wiele wybitnych dzieł sztuki nie musi wywoływać koniecznie poczucia „piękna”), lecz badać proces przeżycia estetycznego wielopoziomowo [Conway i Rehding, 2013]. Ich zdaniem warto rozdzielić "neuroestetykę", zajmującą się poszukiwaniem neuronalnych korelatów piękna, od „neuronauki sztuki”. Pierwsza część tej uwagi nie zasługuje na uwzględnienie, gdyż pionierzy neuroestetyki zdecydowanie nie ograniczają się tylko do poszukiwań „piękna” per se. Conway i Rehding czynią jednak dwie bardzo istotne uwagi: nawet jeśli uda się ustalić, że przykładowo środkowa kora oczodołowo-czołowa (medial orbitofrontal cortex, mOFC) jest głównym obszarem pośredniczącym w przetwarzaniu piękna, to czy jeżeli nie będzie aktywna, to oznaczać to będzie, że osoba nie odczuwa przeżyć estetycznych? Z pewnością nie - osoby z uszkodzoną tą partią mózgu mają problemy z samooceną, ale nie z odczuwaniem piękna [Conway i Rehding, 2013]. Po drugie, nawet odkrycie jakichś uniwersalnych zasad, które cechują wybitne dzieła sztuki, nie gwarantuje, że ich spełnienie umożliwi stworzenie dzieła o wysokiej wartości estetycznej. Takie redukcjonistyczne podejście wydaje się wręcz usuwać istotę geniuszu niektórych artystów, 
czyli to, co miało być przedmiotem badania. Bremer [2016] słusznie zwraca uwagę, że badania neuroestetyczne skupiają się raczej na formie dzieła, nie mówiąc nic o jego treści, która współkonstytuuje przecież emocjonalne przeżycie. Zależeć ona może od różnych czynników, takich jak chociażby kontekst, w jakim dzieło powstało. Można wyodrębnić dwa rodzaje takiego kontekstu: albo dzieło było istotne z punktu widzenia oryginalności, przełamania jakiegoś schematu w historii sztuki, albo z powodu czynników, które nie miały charakteru czysto artystycznego, takich jak chociażby sytuacja społeczno-polityczna, w której tworzył artysta. Jak zauważa Arthur Danto, dwa percepcyjnie identyczne obiekty mogą nieść bowiem zupełnie inne interpretacje $\mathrm{z}$ estetycznego punktu widzenia (np. dzieła typu ready made) [Goldman, 1990].

\section{Wnioski}

Wobec tych uwag wydaje się, że każdy silnie redukcjonistyczny program w estetyce jest skazany na porażkę. Nie dotyczy to tylko mocnej naturalizacji, ale także pomysłów o charakterze bardziej pojęciowym, jak choćby koncepcji Guya Sircello, który uzależnia własności estetyczne od pewnego stopnia zrealizowania własności nieestetycznych. Krytykę tego pomysłu przedstawia Alan Goldman [1990], podnosząc argument, że dzieło o takim samym, realizowanym w pewnym stopniu schemacie kolorów może być zarówno żywe i piękne, jak i „odpustowe” (garish).

Nie oznacza to jednak oczywiście, że neuroestetyka jest jałowym przedsięwzięciem badawczym. W jaką stronę powinna zatem podążyć, by uniknąć mankamentów wskazywanych przez jej krytyków? Użytecznym pomysłem może okazać się adaptacja na potrzeby estetyki znanego z filozofii umysłu podziału na problemy „łatwe” i „trudny", który został przedstawiony przez Davida Chalmersa w kontekście świadomości [Chalmers, 1995]. W odniesieniu do neuroestetyki można by określić łatwe problemy jako poszukiwanie form percepcyjnych, które są w jakiś sposób miłe dla zmysłów, a także neuronalnych korelatów piękna, i tym podobne. Są to osiągnięcia, które prezentują między innymi V. Ramachandran i S. Zeki. Natomiast trudnym problemem byłoby znalezienie odpowiedzi na pytanie, w jaki sposób możliwe jest w ogóle posiadanie przeżyć estetycznych i jaki jest ich neuronalny charakter. Badacze powinni zatem skupić się na odkrywaniu bardziej holistycznych i treściowych aspektów dzieł. Wyjątkowo interesujące może się też okazać badanie nie tylko odbiorców sztuki, ale również artystów w trakcie tworzenia, choć z pewnością będzie to dużo trudniejsze ze względów praktycznych. $Z$ kolei odkrywanie prawideł rządzących przeżyciami estetycznymi może się okazać użyteczne w ramach edukacji artystycznej, gdyż można potraktować je jako pewne wskazówki warsztatowe, które można zastosować w twórczości (bądź w jakiś interesujący sposób im zaprzeczyć). Tym samym nieświadomi neurobiolodzy staną się bardziej świadomi, co może doprowadzić do powstania wielu interesujących i oryginalnych dzieł, wykorzystujących zdobycze nauk kognitywnych. 


\section{BIBLIOGRAFIA}

Ball, P. (2013). Neuroaesthetics is killing your soul. Can brain scans ever tell us why we like art? Nature News. http://www.nature.com/news/neuroaesthetics-is-killing-your-soul-1.12640.

Berker, S. (2009). The normative insignificance of neuroscience. Philosophy and Public Affairs, 37(4): 293-329.

Bonasio, G. (2014). Aesthetic pleasure: cognition and emotion in the aesthetic concepts. Remarks after Sibley's works. Rivista di Estetica, 55: 183-201.

Bremer, J. (2016). Neuroestetyka. Czy przyszłość estetyki leży w neuronauce? W: J. Bremer, Interdyscyplinarne znaczenie neuronauk (s. 69-94). Kraków: Wydawnictwo WAM.

Conway, B. i Rehding, A. (2013). Neuroaesthetics and the trouble with beauty. PLoS Biology, 11(3): 1-5.

Chalmers, D. (1995). Facing up to the problem of consciousness. Journal of Consciousness Studies, 2(3): 200-219.

Goldman, A. (1990). Aesthetic qualities and aesthetic value. The Journal of Philosophy, 1(87): 23-37.

Gregor, M. (1983). Baumgarten's “Aesthetica”. The Review of Metaphysics, 37(2): 357-385.

Huang, M. (2009). The neuroscience of art. Stanford Journal of Neuroscience, 2(1): 24-26.

Hyman, J. (2010). Art and neuroscience. W: R. Frigg, M. Hunter (red.), Beyond Mimesis and Convention: Representation in Art and Science (s. 245-262). Dordrecht-Heidelberg-London-New York: Springer Netherlands.

Kawabata, H. i Zeki, S. (2004). Neural correlates of beauty. Journal of Neurophysiology, 91: 16991705.

Levinson, J. (1984). Aesthetic supervenience. The Southern Journal of Philosophy, 22: 93-110.

Petrażycki, L. (1959). Wstęp do nauki prawa i moralności. Podstawy psychologii emocjonalnej. Warszawa: PWN.

Przybysz, P. (2006). O uchwytywaniu piękna. Rola deformacji estetycznych w tworzeniu i percepcji dzieła sztuki w ujęciu neuroestetyki. W: W. Dziarnowska, A. Klawiter (red.), Mózg i jego umysty (s. 365-385). Poznań: Zysk i S-ka.

Ramachandran, V. i Hirstein, W. (2006). Nauka wobec zagadnienia sztuki. Neurologiczna teoria doświadczenia estetycznego. W: W. Dziarnowska, A. Klawiter (red.), Mózg i jego umysły (s. 327-364). Poznań: Zysk i S-ka (tłum. M. Florek i P. Przybysz).

Rysiew, P. (2016). Naturalism in epistemology. W: E. Zalta (red.), The Stanford Encyclopedia of Philosophy (Winter 2016 Edition). https://plato.stanford.edu/archives/win2016/entries/epistemology-naturalized.

Skoczeń, I. (2016). Czy modny i sprawiedliwy mogą mieć ze sobą coś wspólnego? - czyli kilka słów o thick terms, thick concepts oraz thick properties. Archiwum Filozofii Prawa i Filozofii Społecznej, 1: 55-63.

Zeki, S. (2012). Blaski i cienie pracy mózgu. O miłości, sztuce i pogoni za szczęściem. Warszawa: Wydawnictwa Uniwersytetu Warszawskiego (tłum. A. Binder i M. Binder).

Zeki, S., Romaya, J., Benincasa, D. i Atiyah, M. (2014). The experience of mathematical beauty and its neural correlates. Frontiers in Human Neuroscience, 8: 1-12. 